\title{
Representation of National Heroes in English Language Textbooks Taught at Government Higher Secondary Schools of Sindh, Pakistan
}

\author{
Abdul Razaque Lanjwan Jat \\ English Language Development Centre, Mehran University of Engineering \& \\ Technology, Jamshoro, Pakistan
}

Habibullah Pathan

English Language Development Centre, Mehran University of Engineering \& Technology, Jamshoro, Pakistan

Syed Waqar Ali Shah

English Language Development Centre, Mehran University of Engineering \& Technology, Jamshoro, Pakistan

Received: July 7, 2018 Accepted: September 4, 2018 Published: September 6, 2018

doi:10.5296/elr.v4i2.13612ＵRL: https://doi.org/10.5296/elr.v4i2.13612

\begin{abstract}
Textbooks are not only to read but also inculcate values, virtues and norms of society given in the curriculum. Basically, the curriculum of Pakistani curriculum is broadly based on celebration of history that is taught in different subjects such as, Islamic studies, social studies, languages and Pakistan studies. These all textbooks have been used as a tool to propagate and promote national identity while representing stories of national heroes. These heroes carry certain hidden and intended ideologies. The aim of this research is to explore the textual and visual representation of national heroes of Pakistan who are portrayed in English language textbooks prescribed by Sindh Textbook Board taught in public higher secondary schools. Furthermore, this paper discusses the different elements such as; language, theme, writer's objectivity, use of visuals, and certain ideas in order to explore the hidden ideologies behind representing national heroes. They make students patriotic, nationalistic, militaristic and religious which cause manipulation and exploitation of religion, misinterpretation and
\end{abstract}


mixture of facts, misrepresentation of reality, reinforcement of some practices and so on. This is qualitative method. The textual analysis and semi-structured are proposed methods which are mostly applied in these kinds of research studies. We used the social constructive model as an analytical model for this research to uncover the hidden ideologies represented by the national heroes of Pakistan. They propagate the ideologies of Islam/Jehad, patriotism, anti-India, eulogizing heroes and fundamental divide between Muslims and Hindus.

Keywords: Historiography, National heroes, Ideology, Discourse, Indoctrination, Patriotism, Islamization, Textbooks, Sindh

\section{Introduction}

The textbooks play a role of instrument in socializing children and training them to become true representatives of nation. Their contents are based on such patterns that supply lessons and stories to promote and propagate patriotism (Aliakbari \& Jamalvandi, 2012) (Perko, 2003, p. 101). The sources of values and virtues are discussed differently: family, mass media, peer groups and schools. It is because schools and colleges are busy in teaching values and virtues of society and its people because it is less objectionable (Yazici, 2011). As the method of (Yazici, 2011) stated that what I can say, not as I can do, is not a good method of propagating and teaching virtues, values, customs and norms. The learners and students having need of authentic role models whose deeds, actions, and words should be accurate and consistent and which is good example. Though, the national heroes and their services are directly connected to classical method of values and virtues (Yazici, 2011), the students centered methods would consider hero as a role model while teaching virtues, values and norms. The sole purpose of representing hero in particular education reflected that the sentimental and emotional sides of norms, values and virtues, using different role models and national heroes may be effective in promoting and propagating the true spirit of patriotism.

The practitioners and theorists of nationalism have much emphasized on the importance of national heroes in unifying and defining the community. In Pakistan, language teaching and learning is totally based on textbooks. These act like a pedagogical tool for teachers and students as well. It creates bond between the culture, language and politics of the society and its people. Originally learning and teaching in Pakistan solely depends on curriculum which is totally based on the history. The history of Pakistan is taught in different subjects, particularly, social studies, languages, Pakistan studies and Islamic studies. Inside the STB, the current study focuses on the visual and ideological representation of nationalism. It denotes the beliefs, ideas, customs, themes and attitude carried by the national heroes and commonly shared by all the people who are living in Pakistan, for example religion, patriotism, nationalism, national identity, etc. These are themes have been incorporated under the umbrella term of nationalism in the representation of national heroes in English Language textbooks.

\subsection{Aim \& Objectives}

This study aims to investigate the representation of national heroes in English language textbooks taught at Government higher secondary schools of Sindh, Pakistan. The following objectives have been addressed in the present study: 
- To investigate the visual and textual portrayal of national heroes represented in English language textbooks of province Sindh, Pakistan.

- To explore intended and hidden ideologies spreading and promoting the national heroes of Pakistan.

- To investigate whether or not students at government schools are aware of intended and hidden ideologies of national heroes portrayed in higher secondary level English language textbooks.

\subsection{Problem Statement}

Nationalism and patriotism in Pakistan are contested subjects. What makes us Pakistanis and what is it that makes us love our land and nation? The answers to these questions vary widely depending on who is being asked. A large part of our national identity stems from our sense of history and culture that are deeply rooted in the land and in the legacy of the region's ancient civilisations. Religion has also played a big part in making us what we are today. But the picture that textbooks paint for us does not portray the various facets of our identity. Instead it offers quite a convoluted description of who we are. The distortion of historical facts has in turn played a quintessential role in manipulating our sense of self. What's ironic is that the boldest fallacies in these books are about the events that are still in our living memory.

We tend to investigate the portrayal of Pakistani national heroes in English language textbooks which are taught in public higher secondary schools of Sindh, Pakistan at which are taught between (14 to 18). This is a study of Government schools and colleges of Sindh, Pakistan. It is observed that the national heroes represented in hyper-national tone much focused on the ideologies of Islam, patriotism, anti-India and so on. The curriculum designers and developers mentioned only such national heroes who contributed in partition of sub-continent and war heroes but they never bother to include social heroes and heroes of different field who served and contributed a lot for nation and country

\subsection{Research Questions}

The research questions for the present study are formulated as under:

- How national heroes of Pakistan are visually and textually portrayed in English language textbooks of higher secondary levels?

- What are the hidden ideologies of national heroes represented in English language textbooks of higher secondary levels?

- How far students at government higher secondary schools are aware of hidden ideologies of national heroes which are portrayed in Sindh Textbook Board English language textbooks?

\section{Literature Review}

The language plays a crucial role as it usually reflects person's background, social standing and his mental inclination (Khan, Sultana, Bughio, \& Naz, 2014, Pathan et al., 2018). This is even applied in context to textbooks and the stuffs that are contained in them. It is also then used to reflect, portray, project and reinforce culture, race, gender, identity, people, religion and existence. Because, language is a medium or source through which the cultures, norms, manners, methodology and morals of the society are carried from one generation to next generation (Khan et al., 2014, Shah \& Pathan, 2016). It is also a medium for the internalizing 
and transmitting ideas, conceptions, themes and ideologies. Moreover, Julia T. Wood (2007) $\&$ Pathan et al. (2015) noted that language shows and reinforce values, rituals, cultural values, including about gender (p. 114). The country Pakistan had tried hard to re-invent and re-imagine itself after 1947. A long period of colonial rule, teaching an Islamic and nationalist can be seen in the form of curriculum and social cement binds the nation in one page. The building of Pakistani national identity and nationalism is explicitly instructed through school's programs of civic and social studies.

The main role of heroic, enigmatic personalities in helping and guiding to forge the nations out confrontation to outside supremacy and subjugation is the most powerful facet of romantic nationalism (Smith 1999; Hutchinson, 2004). And when knotted to emergent government education system in both $19^{\text {th }}$ and early $20^{\text {th }}$ centuries, the chief responsibility in those systems were assumed in the formation of nationalism and national identity (Weber, 1976; Richardson, 2002), but combination of heroic with pedagogic served confidently to create an authentic stimulus in order to assist national identity and nationalism. These two factors also served to aid to form nationalism and nation's identification with the nation and the state. It has been a long avenue along with nationalism and nation building ways were carried out in the schools while bringing historical and inspiring stories, lessons and texts of national heroes to the people through history, PS textbooks and language textbook. Such type texts when observed over time surely reflect attractive narratives of varying concepts of nation and shown what Tom Nairn (1999) had rightly termed that the "Janus-faced" nationalism and nature of national identity, they have more than temporal development of pictures and images of nation. If textbooks of schools and colleges seek to stimulate and inspire nationalism, means patriotism through emotive portrayals of the feats of national figures, martyrs and heroes, they also can seek to legitimize and historicize leading concepts of nation. As scholar of post-colonialism, Homi Bhabba reminded us that it is a first duty of state to give its nation's cultural and national identity as well as develop (Presented \& Conference, 2010). The great leaders and heroes have binding force that has destined upon them and they have been also chosen for noble cause and heroic mission. However, this their noble mission and goal begins with certain crises, but sometimes inspiring leaders and heroes' welcome and even create the crises. Hence, it may be argued that national leader and national hero is sometimes same figure as a great charismatic leader. The national heroes are those who have strong beliefs and concepts of nation and afterward struggle for the freedom of their country. Nations, according to the views of Bhabha (1999), "like narratives and texts lose their backgrounds and origins in myths of time but fully look for their horizons in mind's eyes. These type of image or texts could seem unbelievably excessive metaphorical and romantic, but such took birth from these traditional political ideas and thoughts, the literary languages as the most powerful historical thought". Moreover, in the metaphorical and romantic contexts, a charismatic leader has given mythic and vital roles in the nation building. In Anthony Smith's term "a hero depicts the best of community's values, traditions, norms and views, and its genuine voice at the twinkling of its first flowering" (Presented \& Conference, 2010).

\section{Research Methodology}

The present research study is basically qualitative in nature. Qualitative Research 
encompasses the collection of widespread narrative data for gaining the intuitions into the phenomenon of interest. We used mixed research tools like textual evaluation and content analysis to collect data and determine the representation of national heroes of Pakistan in textbooks either students are aware of ideological impacts or not.

\subsection{Textual Analysis}

Textbooks evaluation is a process of making a judgment on the quality and suitability of material in the book (Hatoss, 2004). Hutchinson and Waters (1987) explain evaluation as "judging the fitness of something for a particular purpose" (p. 96). Sheldon (1988) presented many other factors and reasons for the textbook evaluation such as administrative, political and financial reasons. For this study, I will select different scripts from English language textbooks, taught in Years 14 to 18 in public higher secondary schools of province of Sindh, Pakistan.

\subsection{Content Analysis}

This is an authentic method in qualitative research which helps the researchers to explore meanings and images given in the texts in various contexts. Das and Bhaskaran (2008) viewed that content analysis is an important method that is an authentic in the study of social phenomenon like discrimination, prejudice, biases, and national identity. Moreover, mostly researchers divide the documents into related themes and also subthemes to know hidden and intended messages and ideologies in the contents.

\subsection{Data Collection Source}

For this paper, data comes from text evaluation. The textbooks of English 9, English 10, and Intermediate English book one and book two that are taught in government higher secondary school of Sindh, Pakistan. These all books have been prescribed by Sindh Textbook Board according to National Curriculum of Pakistan 2006. There are twenty-one lessons in English 9, twenty-three in English 10, ten lessons in each intermediate English book 1 and book two. We selected texts based on the narratives of national heroes. Further, we divided national heroes in two categories: partition heroes and war heroes. For analysis, the Sindh Textbook Board will be referred to as STB. The research also tries to attempt at seizing the aspirations and attitudes of the students towards ideological themes of nationalism, patriotism, Islam/jihad, religious othering, hatred, indoctrination of patriotism, religious and national heroes encoded in language texts, lessons and stories to understand how these such textbooks ideologies affect, impact and shape the minds of students in Pakistani schools.

\subsection{Data Analysis}

We applied textual analysis for the textbooks. This research employed a Social Constructivist as a theoretical framework for the present study. This framework was introduced and applied by two researchers Van der Wat and Wolhuter in their research studies. They both employed this method of research in textual representation of two former Leaders of South Africa, President -Nelson Mandela and F. W. De Klerk. We used this framework in this study for textual analysis of national heroes of Pakistan. It was employed for the textual analysis of the texts related to religion/Islam, national identity, nationalism, patriotism and war/jihad in earlier above mentioned English textbooks. For this, the analysis has been carried out at sentence levels. While sentence have been purposively selected from the texts in said 
textbooks. The reason for purposively selection of sentences/ statements/lines instead of full passages is the amply of material related to the national heroes and their intended and hidden in the textbooks.

\subsection{Explanation of Key Terms}

\section{a) Presupposition/Assumption/Implication}

These terms refer to deducing and inferring implied meanings from the lessons that we go through. The fact is that the communities usually share meanings among their members and they can easily know them. The shared knowledge within the community can give birth to cultural, political, ideological and social supremacy and dominancy.

\section{b) Identity}

The term "identity" basically indicates who we are and what ideological group we related to. Many philosophers, scholars, sociologists, psychologists, anthropologists, linguistics and so many others have tried hard to define "identity" while giving different points of view. According to Fearon (1999) cited in Yaqoob (2011, p. 65), the term "identity" is used in different two senses: personal and social. There is a dialectic connection between personality and social identity: while social roles impact people's way of seeing, changing and perceiving the social lives.

\section{c) Representation}

Representation means a sign, mark of something or someone particular; or describing something or someone in specific way to form a particular idea or opinion about them.

For example, the people who are in politics and elected people represent their country and people in parliament. Similarly, in language, the symbols and words stand for certain concepts, ideas, facts, feelings, emotions, etc. are their representations. For understanding, the representations mostly depend on existing images and signs, on the learnt mutuality of language and different textual systems (Hartley 2004, p. 202). This the functional facet of language-sign or word that helps us in understanding and learning reality. In this context, the representations may rightly be considered as a real form of language. More importantly, there is way of selection of symbols and signs in order to represent things specifically linked to our social, cultural and political life; for example, class, groups, sects, nation, etc.

\section{d) Difference}

The difference has very close meaning to attribution of voices or dialogcity. However, the term "difference" is applied to explore the variations in cultural, social, religious, political and ideological domains. This current research study determines the hidden ideologies of national heroes' differences to some extent.

\section{e) Universalization}

The term "universalization" refers to ascribing a universal importance of something in making it more acceptable and legitimate. This is very serious problem and ideological issue as discourses that contain different ideas, concepts, values, beliefs, practices and ideologies which are commonly represented as universal. Yaqoob (2011, p. 68) stated that such ideas, concepts, values, beliefs and notions are universalized in texts and lessons or given universal status for the ideological purposes. 


\section{Findings and Discussion}

We mentioned and discussed about the selected national heroes of Pakistan who are portrayed in English language textbooks of Sindh Textbook Board. Furthermore; the study of this chapter is based on the analyses of the given below texts, which are divided into two different groups.

\section{The Texts on National Heroes}

\section{Partition Heroes}

Allama Iqbal - for Year 9 in English

Quaid-i-Azam Muhammad and his vision- for Year 9 English

Begum Rana Liaquat Ali for Year 11 in English

Shaheed-i-Millat, Liaquat Ali Khan for Year 12 in English

\section{War Heroes}

The Great War Hero (Major Aziz Bhatti) for Year 9 in English

\section{Textual and visual representation of National Heroes of Pakistan}

The most prominent feature of the selected texts is to give genuine and factual specifics such as date of birth, family details, place of birth, education, etc. Almost all given specifications and descriptions are slightly ambiguous, making claims and statements without solid factual information that aiding it. For instance, he fought in War bravely (from Secondary School English, 2017a), or Dr. Allama Iqbal is broadly known as a great poet (from Secondary School English, 2017b). In same way, few of them replicate the final words or phrase of national hero of Pakistan. However, it can be hard to record the actual words of a person who is dying in battlefield, which is usually the case. Hence, the different quotes for every war hero may be fictitious and looks more such devices that are applied to evoke nationalism, courage, patriotism and Islamization than the close actual reality.

The picture of prominent and historical personality most of the time is accompanied. When they present, the pictures of the national hero are located before the written extract starts or at the beginning. The sizes of the pictures are given differently. Some are in passport size and some are in a full page. All given images can be seen in black and white, but cover pages are shown in colour. Moreover, all the images are portraits individually, and there is hard to find a representation of any person or any event which are around them. The satire, cartoons and caricatures are neither used.

\section{Partition heroes.}

The achievements and the lives of independent heroes is an important topic for school textbooks. Sometimes, many texts are found on same particular hero. The formation of India and Pakistan is a prominent event in the history of subcontinent.

Quaid-i-Azam Muhammad Ali Jinnah (9 level School English Language textbook, pp. 59-60). This lesson is based not on the life of Quaid-i-Azam but on his services and vision behind the creation of Pakistan. This also represents Quiad-i-Azam as one of the greatest leaders and personalities of South Asia. It is also portrayed here that Jinnah was not only leader of Muslims but also Hindus, Christians, Sikhs and Parsis. He was ambassador of Hindu Muslim Unity. He was a man who intelligently pleaded the case of a separate 
homeland for Muslims and succeeding in getting Pakistan. This is clearly reflected in this statement,

"He envisioned the Pakistan, a pluralistic society, as a "nation state" ensuring equal rights for all as citizens of Pakistan” (pp. 59-60)

He did not want separate homeland for only Muslims but other communities, but he wanted a separate homeland Pakistan beyond from any race, caste, religion and community.

The lesson in this statement reflects,

"You are free; you are free to go to your temples; you are free to go to your Mosques or any other place of worship" in this State of Pakistan (p. 60).

These above given statements of Quiad-i-Azam reflect that he was not only leader of Muslims but also the leader of all the races and religions. But this is again controversial statements. It was his earlier vision when he was a member of Indian National congress.

While representing the Quiad-i-Azam and his vision the language tone is very kind and full of sympathy. He propagated the equality, fraternity and brotherhood.

Allama Muhammad Iqbal (9 level School English Language Textbook, pp. 36-39). This text is based on the services and life of Allama Iqbal, widely known as poet of East and National Poet of Pakistan. He presided the famous session of All India Muslim League at Allahabad on $30^{\text {th }}$ November, 1930. Many scholars and historians contradicted on the point that Allama Iqbal had presented the original idea of Pakistan, separating majority of Muslim provinces of Sub-continent to establish a new Muslim state for the first time (Jalal, 1994). This idea of separate homeland is propagated in many textbooks, including this and this text reflected that Allama Iqbal saw the dream of Punjab, Sindh, Balochistan and NWFP under the umbrella of Pakistan. However, many critics reject these claims that Allama Iqbal only wanted partition of Sub-continent for a separate Muslim state, but he only wanted equal rights for the Muslims of India (Moore, 1983; Naim, 1979; Qureshi, 1969). Furthermore, Jalal (2002) viewed that famous Lahore Resolution of 1940 even did not discuss or mention the true idea of Pakistan. In one letter to the founder of Pakistan, Quaid-e-Azam, he wrote,

"Don't you think that time for such demand has already arrived?" (p. 38).

On this similar note, another statement is given:

"The Muslims woke from their sleep as a result of Allama Iqbal's efforts..........." (p. 38-39).

But this contradictory because Allama Iqbal earlier died in 1938 and country got its independence after nine years in 1947. This text entirely reflects the ideology of Islam and factors of Muslim's existence and safety of the subcontinent, claiming that Pakistan got independence on the bases of Islam and that Pakistan is only a state for Muslims (see also, Zafar, 2015). As in following statement, he says,

"In united India where the Hindu majority would rule the country, the Muslims could not develop freely".

Allama Iqbal also propagated Islam and Islamic ideologies. He himself believed that he had strong faith in Islam and it is Islam that could save from the difficult moments and crises.

Liaguat Ali Khan (Intermediate Textbook two, pp. 44-49). This text starts with the brief life history of Liaquat Ali Khan, his education and services for the creation of Pakistan. This text 
reflects about the first Prime Minister of Pakistan, Liaquat Ali Khan, and his snuggle for the independence of Pakistan that is further highly described in a high patriotic tone.

The first paragraph of this text also informs its readers that Liaquat Ali Khan delivered famous speeches on how Pakistan was born and how he faced problems during first crucial years of Independence. It also informed about the readers that Allah bestowed Liaquat Ali Khan with the honor of a martyr and ends with the huge loss of nation, and also explaining that by killing Liaquat Ali, the shooter made him Quaid-e-Millat (Leader of the nation) and Shaheed-e-Millat (Martyr of the nation). In this lesson, different religions like Hindus, Muslims and Christians were discussed. He talked about the religious differences. He further promoted Islam in the following statement when he says:

"Their economic outlooks were also different. Muslims believed in the right of private ownership for everyone, whether man or woman, and has a law of inheritance...... unlike of those the Hindus were designed to promote the distribution of wealth and discourage vast unearned accumulations" (p. 45).

Moreover, this text also informs us about the early difficulties and attitudes of both British and Hindus during the creation of Pakistan. The text reflects hatred against British and Hindus. In this statement the elements of hatred and patriotism is clearly observed:

"When British India was partitioned we, the Pakistanis, were asked to set up a new state of eighty million people within a period of two months. We had no capital and no flag...our share of the military equipment of British India which was allotted to us on paper remains largely undelivered even today" (p. 47)

These words expressed emotionally and gave the reflection of early days of Pakistan, how they faced problems and how they were treated by Indians during partition of India; they were not given equal share in capital and military equipment. The narratives of such texts are given in order to arise hatred against Indians in the minds of readers and students.

Female national heroes (9the Grade English language textbook, pp. 44-49). This is only a lesson that is on female national heroes in Pakistani textbook. The portrayals of these female heroes are represented with their images. Basically, these were not common ladies but belonged to Pakistan Movement heroes who served their lives for the separate homeland Pakistan. Among them, the most influential lady was Begum Rana Liaquat Ali Khan because she was the wife of first Prime Minister of Pakistan, Liaquat Ali Khan who was a great devotee and sincere leader to the cause of Independence of Pakistan.

This is the only text that represents the role of women in Pakistan Movement. In this text, the theme patriotism can highly be reflected throughout the lesson. However, the text in English language is on female hero, the tone and expressions are quite serious, solemn and sincere. While representing Rana Begum Liaquat Ali, many facts and figures are clearly given, for example, she was awarded and honored with UNHR (United Nations Human Rights) Award in 1978. It is also represented that Begum Rana was first Muslim lady among the active women who played an important roles and parts in encouraging and motivating the Muslim women as also professionals, particularly the field of nursing at that time. While representing her, they do not use boastful and effective language or a language that arise sentiment, emotions and feelings to the extent as it does in other languages 
In this text, the pictures and images of female heroes are given in blacken white but in small size. They are represented as the supporters of national heroes who fought for the cause of Pakistan. Their language is simple and not aggressive as compared to other national heroes.

\section{War heroes.}

The school and college textbooks of Pakistan have been widely criticized for sentimentalizing the India-Pakistan war soldiers as martyrs, sons of the land and heroes; hence provoking discrimination and hatred against the non-Muslims, especially anti-India (Nayyar and Salim, 2003; Harrison et al., 1999). Continuing this same pressure, Nayyar and Hasnain (1999) viewed that recent history, for instance, the wars between India and Pakistan are distorted by absolving the blames for such events that led to wars. In 2003, Saigol noted that how course textbooks are depicting Pakistan's military as challenging and winning much over a huge Indian military, acclaiming that Pakistan's army is one the best armies of the world. She also explained that this was happened after the humiliated loss of East Pakistan, means Bangladesh in 1971. The reputation of army and its powers were badly damaged with the separation of East Pakistan.

The Great War Hero (9 grade English Language textbook, pp. 74-75). This short text gives honors and tributes to Major Aziz Bhatti on the achievements and love of his country. Who fought for country and received the highest military award, Nisha-e-Haider in Pakistan. However, approximately one half of writing mainly focuses on day of his martyrdom in 1965 war with India. The text propagates and promotes the concept of patriotism and religion especially the spirit of jihad. These two themes and ideologies can clearly be understood from the text. This statement states:

"The Indian were equipped fully with guns and tanks" (p. 75), "Major Aziz Bhatti was fired with the true patriotic spirit of a disciplined soldier. With his small company he not only stopped the Indian advance but also pushed them back" (p. 75).

Another statements, the text reflects,

Major Aziz Bhatti, "who was filled with the spirit of Jehad replied, "Do not recall me. (pp.75)

These types of statements are full of passion, enthusiasm, commitment and fill youth's minds with different extreme feelings about homeland and against the enemies of the country. These words and aggressive language can inspire the youth of Pakistan with confidence and courage.

There are two pictures which are portrayed in the text, one of the hero himself and other the highest military of Pakistan award of Nishan-e-Haider, which Major Aziz Bhatti was honored after his death in 1965 War with India. The image of Nishan-e-Haider propagates and promotes patriotic spirits. This could be supported by the last line of the text, "these words will ever inspire the youth of Pakistan with confidence and courage".

\section{Textbook Evaluation and Ideologies represented by National Heroes}

Besides the representation of national heroes, there were other very important observation that were reflected in the texts. Among them, the hyper-national tone is present in language. There is also a very much tendency and efforts to embellish and sensationalize the narratives/scenes, in few of them, by tallying a portrayal of surroundings and setting. It is also 


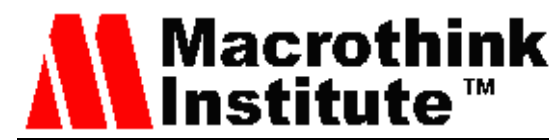

find out that the display of patriotism is made accessible in English language on the war heroes. The main reason behind this hypersensitivity and sensationalizing are the barriers of language because people can get attracted easily in their own language. It is also easier for the authors as well. Even though, these texts serve promoting and propagating the ideologies and themes regarding national heroes of Pakistan. While representing national heroes, the major themes and ideologies are observed like Islamization, anti-India feelings, indoctrination of patriotism, war/jihad, nationalism, etc. Each of these is evident even when getting a separate country, i.e., Pakistan in case of partition heroes, or dying for the country in case of war heroes (see also, Aziz, 1998).

\section{Fundamental divide between Muslims and Hindus}

The ideological messages in this current study showed nationalism, Islamization, patriotism and fundamental divide between Hindus and Muslims. STB (Sindh Textbook Board) English language textbooks are the best examples of such themes and ideologies which are promoted and propagated through the narratives and representations of national heroes of Pakistan

This is taught to the students and youth of Pakistan in the textbooks that Pakistan was formed solely because of a fundamental conflict between Hindus and Muslims. This idea bases itself on the notion of a civilizational divide between monolithic Hindu and Muslim identities, which simply did not exist. The stress on religion ignored other factors that could cut across both identities. This idea is clearly observed in the following figure.

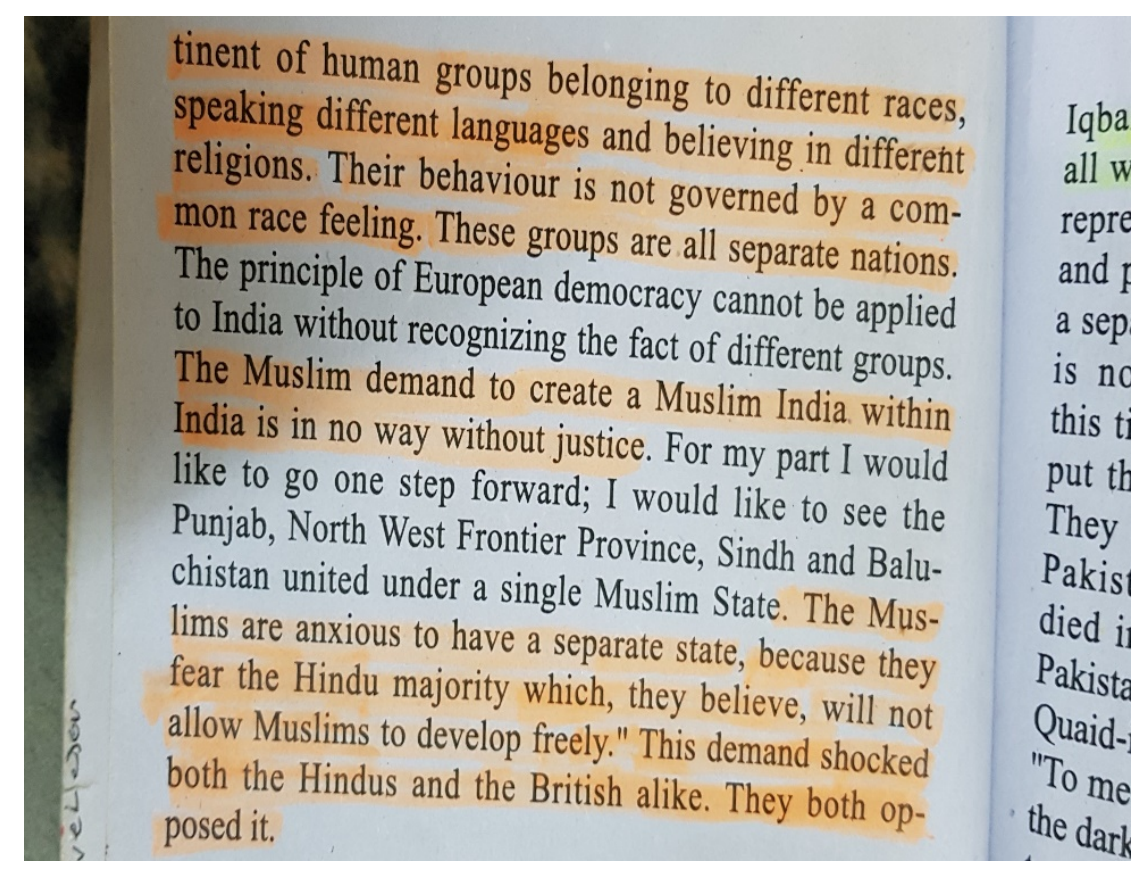

Figure 3. Image from STB-9 (English Language Textbook)

This picture reflected that Allama Mohammad Iqbal propagated the separate homeland for the Muslims of India due to fundamental differences. They are two different nations. In his presidential address, he said that Muslims are very keen to have a separate country, because Muslims and Hindus are two different religions, they belong to different race, they speak different languages and believing different religions. He states in his presidential address Dr. 
Iqbal:

"India is a continent of human groups belonging to different races, speaking different languages and believing in different religions. Their behavior is not governed by a common race feeling. These groups are all separate nations". ( $9^{\text {th }}$ English pp. 37-38).

These lines in above image clearly reflect the fundamental differences between Muslims and Hindus which is represented in the portrayal of Allama Iqbal. He believed that the Hindus and Muslims are two different religions. They have language and religion differences.

The theme of fundamental differences of the Muslims and Hindus can be reviewed in the Intermediate English book two which is based on Shaheed-e-Millat, first Prime

Minister of Pakisatn, Liaquat Ali Khan. The lesson "Pakistan and The Modern World" is based on the portrayal of Liaquat Ali Khan and his message to the youth of Pakistan. He has discussed about the fundamental differences of Muslims and Hindus. He states,

"It was not merely a question of religious differences, as that phrase is generally understood. It was not merely that whereas the Muslims were monotheists, the Hindus were polytheists, or that the Muslims believed in the Prophet of Arabia, whereas the Hindus did not. (Intermediate English Book Two, p. 45)"

\section{Eulogizing Heroes}

In his preface to the Muqaddimah, Ibn Khaldun warned of seven mistakes that he thought historians often committed. One of the seven is "the common desire to gain favour of those of high ranks, by praising them, by spreading their fame." This particular trend and mistake has been practiced in history writing and in representing national heroes for school texts in Pakistan since the 1950s and has been used as a political tool to project successive rulers whether civilian or military - in a eulogistic format.

Moreover, another mindless inaccuracy is the absence of the 'other', where India and Congress are needlessly ignored and a one-sided version of history is deemed necessary for creating a nationalistic mindset. Many Muslins leaders were in related to Indian Congress and worked against British rule but their names were not given in Pakistani textbooks. This gap continues in the historical narrative for school students post-partition. Hence, some of the most blatant lies and subversion of historical facts exist in the textbooks mandated by the federal and provincial textbook boards. Furthermore, maligning the 'enemy' is done quite overtly and mindlessly in official English language schools' texts which, unfortunately, is also the case with some Indian school texts documented by discerning authors on both sides of the border. In one letter to the founder of Pakistan, Quaid-e-Azam, he wrote,

"Don't you think that time for such demand has already arrived?" (p. 38).

On this similar note, another statement is given

"The Muslims woke from their sleep as a result of Allama Iqbal's effort" (pp. 38-39).

This is very contradictory statement because Allama Mohammad Iqbal was died before the independence of Pakistan in 1938. But the text shows that Pakistan got independence due to the hard efforts of Allama Iqbal. It reflects that how national heroes are eulogized in their narratives and stories. There were many Muslim leaders and heroes who fought for Pakistan and her independence not only Allama Iqbal. 


\section{Al Macrothink}

\section{Islamization}

The most important ideology that covers page after page of history and language textbooks is that Pakistan was created for the propagation of religion. In fact, when the Muslim League was established in Dhaka in 1906, one of the foremost principles was the creation of loyalty to the British rulers and to promote greater understanding between Muslims and the British government.

The significance of Islam to Pakistani nationalism and identity is one of the important themes in the textbooks. The textbooks establish vital role of Islam in describing and defining ideological basis of Pakistan. The students read that Muslims of Sub-Continent got a separate state so that they could give the practical shape to final and outright authority of Allah Almighty. It is a fact that Islam is the ideology of Pakistan because it has a reasonably recent origin and no any text was written prior to year 1977 mentioned ideology of Pakistan (Muhammad, n.d.). There generally seems to be a visible effort for the ruler of the country to Islamize the history of Pakistan. Rahman (2005) writes that during General Zia's time, "Islam was used to support the state's own militaristic policies in a way that it appeared to the readers of these textbooks that Pakistan, the Pakistan movement, Pakistan's wars with India and the Kashmir issue were all connected not only with Pakistani nationalism but with Islam itself" (Rahman 2005), p. 27). Islam is made a defining factor for Pakistanis, regardless of ethnic minorities. There is also a strong inclination towards showing Pakistan's cultural association with the Arab world. Conversely, it refuses cultural descend from India or even introducing other cultures to develop cultural harmony and tolerance (see Ahmed, 1998).

History textbooks portray "Two Nation Theory" as the ideology of Pakistan. They explain religion as the dividing factor and the reason behind the creation of Pakistan. This is apparent in this chapter. However, Jalal (2002) and Hoodbhoy (1998) argue that the term 'ideology of Pakistan' did not exist at the time of the creation of Pakistan and Quaid-e-Azam Muhammad Ali Jinnah, the founder of the country, never used it and is an after-thought. The term is never used in any of Jinnah's speeches or writings either (Pirzada, 1970). The critics doubt the existence of Islamic ideology of Pakistan at the time of its creation and even after for nearly a quarter of a century (Ahmed, 2001, Ahmed, 2012, Haider, 2010).

The element of the supernatural is evident throughout, though it is more clearly voiced in English. In the text of Allama Iqbal, God is shown as responsible for partition of India. Similarly, Iqbal's famous Allahabad address is stated in the following image which also reflects his concept of supernatural evidence. 


\section{Macrothink}

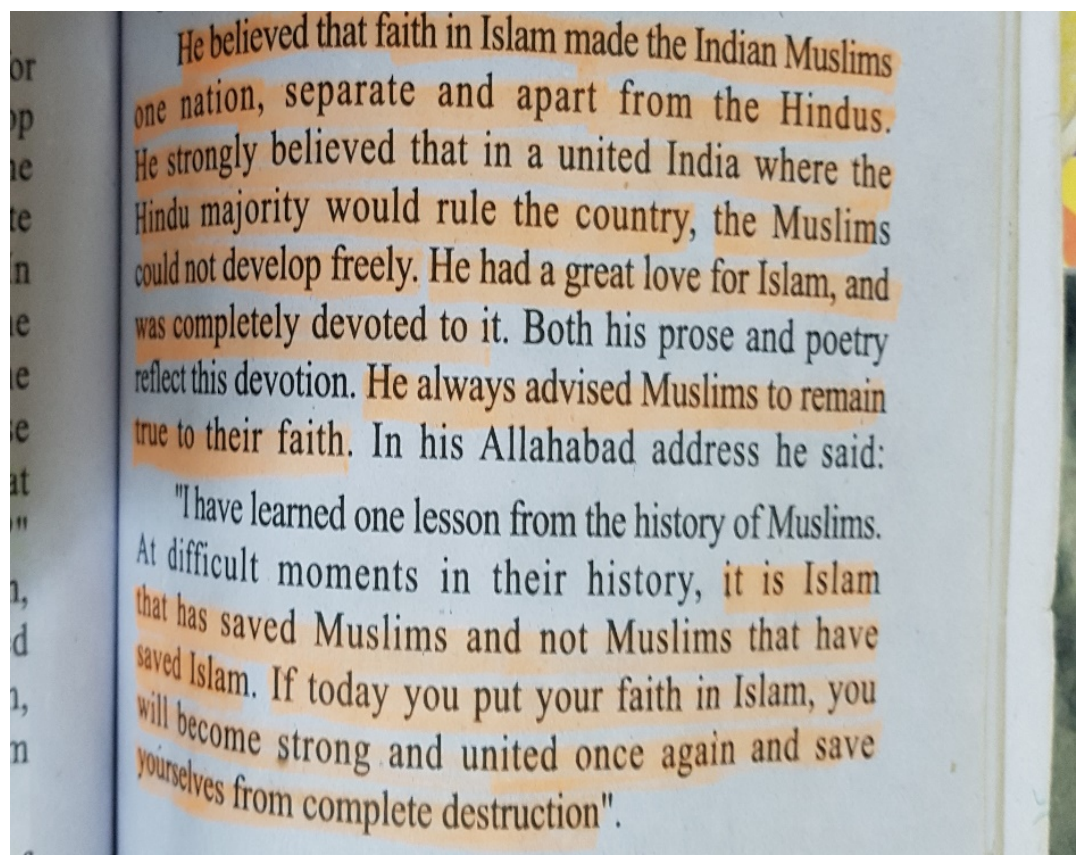

Figure 4. Image from STB-9 (Representation of Islam)

In this image no.4, Allama Iqbal strongly is shown to be a believer of Islam. He has blind faith on Islam. According to him, Islam is a religion of faith and unity. The Islam has a great power to save Muslims from the atrocities of the Hindus. He in his famous presidential address, he quotes:

"I have learned one lesson from the history of Muslims. At difficult moments in their history, it is Islam that has saved Muslims and not Muslims that have saved Islam. If today you put your faith in Islam, you will become strong and united once again and save yourselves from complete destruction" (p. 39).

However, critics agree on Iqbal being anyone but a fervent Muslim, thus defying the often-quoted famous words as creative rather than true (Paracha, 2013).

\section{Jihad}

The theme and ideology of Jihad is also being propagated by the national heroes of Pakistan. This is very important pillar of Islam. It has a great importance in Islam. This ideology is also promoted by the portrayals of national heroes. The portrayal of Major Aziz Bhatti propagates the ideology of Jihad in very aggressive and boastful manner. In the following figure no.5, the spirit of Jihad can be reviewed. 


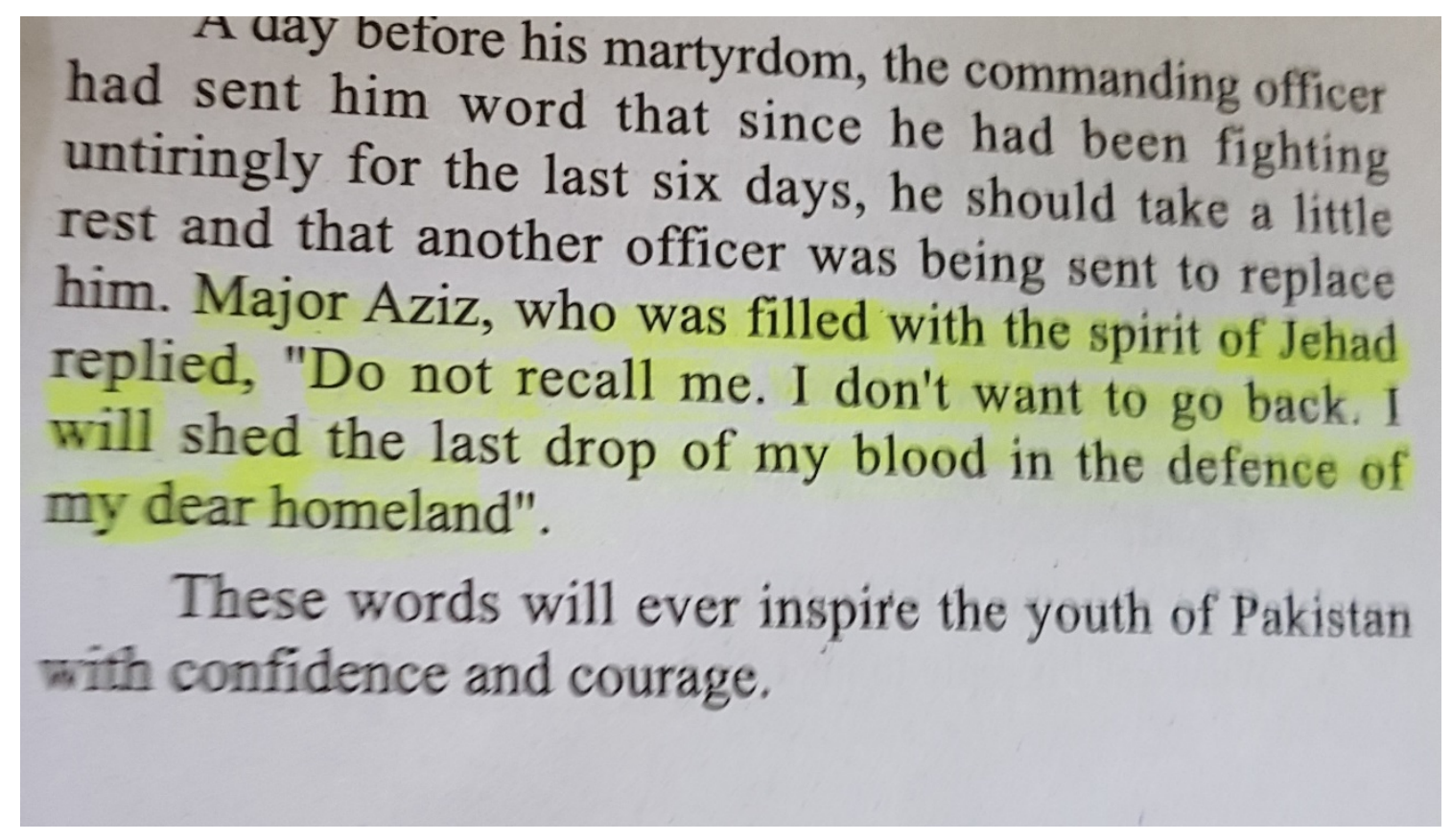

Figure 5. Image from STB-9 English Language Textbook (Representation of Jehad)

In this image the ideology of Jihad has been promoted and propagated. Major Aziz Bhatti was a great national hero, who fought for the defence of the country. He is role model for the youths of Pakistan.

\section{Anti-India}

It is stated in history or language textbooks that India is ultimate enemy and threat for Pakistan, and also busy in planning tactics for the destabilization of Pakistan. The curriculum of Pakistan for this regard seems to be focused more on informing Pakistani young children to be aware of their enemy. Similarly, these textbooks also accuse India for the disasters and mishaps the state has faced, including three different wars among neighboring countries: the separation of Bangladesh (East Pakistan), the Kargil conflict and the Kashmir issue. In portrayal of Captain Sher Khan in Urdu textbook, Indians are considered as the worst enemies of Pakistan (p. 67). This shows that these kinds of statements informing the learners how Indians were cruel and disloyal to Pakistan. This same kind of feelings can be seen in the portrayal of Allama Iqbal in $9^{\text {th }}$ level English language textbook. It says that the Muslims wanted a separate homeland because they had fear that the Hindus are in majority and this thing would not have allowed them to live freely in Sub-continent. The text reflects,

"The Muslims are anxious to have a separate state, because they fear the Hindu majority which, they believe, will not allow Muslims to develop freely" (9 level English textbook, pp. 38).

This text shows Muslims' attitudes towards the Hindus. They consider them their strong enemy. It can give anti-Hindu feeling and hatred to the youth of Pakistan. This also gives the views of national hero, Allama Iqbal regarding the attitudes of the Hindus towards the Muslims. When students read about Allama Iqbal, they get feelings of hatred. This portrayal of Allama Iqbal promotes and propagates anti-Indian feelings. With this issue, another very 
sensitive issue was the migration of people at the time of separation or independence. This is widely known as a huge migration in history of the world. They were around ten million people who were migrated to Pakistan. Among them, a million were laid dead due to riots and rivalries among common people (Bates, 2011). It was first time when Muslim demanded a partition of India in Lahore Resolution by Muslim league on March 23, 1940 but no one of its clauses mentioned the migration of common people from both sides of the border. But the textbooks give the picture of those miseries in one-sided way while explaining the miseries of the Muslims how they faced hostilities from Sikhs and Hindus. The curriculum designers had failed to give clear picture and explanation on how common people of United Sub-continent generally suffered not due to religious hatred and differences. Recalling the past harsh incidents in textbooks would not lead the nation into progress, it would indulge them in past events and incidents.

The propaganda of Anti-India is directly connected to main theme of Islamization relating the ideology of Pakistan with belief, faith and principles of Islam that are presented through the English language (Nayyar \& Salim, 2003). There is extensive disbelief for ethnic minorities especially Hindus, and no room for them in Pakistan. But this idea is giving negative impact of Pakistan and also negating true concept of flag of Pakistan because one third of it represents minorities and their religions.

The text of Major Aziz Bhatti reflects the ideology of anti-India in very aggressive manner. Because it is war national hero, therefore, his portrayal is very aggressive and full of hatred against the India. This statement clearly reflects,

"The Indians were fully equipped with guns and tanks" (9 level English, p. 75)

This text is based on the war hero who promotes and propagates feelings of hatred against the Hindus/Indians in very aggressive manner in order to inspire the youth of Pakistan against the Indians.

\section{Indoctrination of patriotism}

The above mentioned all ideologies and themes are very important but the most important among them is the theme of patriotism. Paracha (2013) explained, "Over the many decades, these textbooks, which are taught regularly at schools of Pakistan, have evolved slowly and gradually into becoming one-dimensional manual that is of how to believe, become and behave as a true Pakistan". Such type of textbooks does not need to develop a sense of equality, tolerance and peace. Moreover, he said that the subject such as Pakistan Studies was introduced as a compulsory subject by then Prime Minister, Zulfiqar Ali Bhutto and his government while applying indoctrination as a tool after the loss of East Pakistan. However, after the government of Zulfiqar Ali Bhutto, a military dictator General Zia-up-Haq and his government made all sorts of efforts to raise extremism in common people, that is the main cause of the problems and challenges that Pakistani nation is facing now (see also, Ali, 1998). It can be agreed with Loewen (1995, pp. 14-15), "the textbooks are mostly mixed up by the controversial and conflicting desires to propagate and promote inquiry as well as to indoctrinate the blind patriotism".

The words of "Shaheed" for martyr are sufficient word to promote the patriotic spirit among the readers. These words are not for just war heroes but for other partition heroes in their 
narratives which can arise patriotic spirit. The ideology of patriotism is clearly seen in the portrayal of Major Aziz Bhatti. This statement reflects,

"Major Aziz Bhatti was fired with true patriotic spirit of a disciplined soldier. With his small company he not only stooped the Indian advance but also pushed them back". ( $9^{\text {th }}$ English language textbook, $p$. 75)

In these lines, the spirit of patriotism is promoted and propagated emotionally and sentimentally.

\section{Conclusion}

This research study is basically based on an evaluation of texts on the services and lives of Pakistani national heroes who are represented in higher secondary English language textbooks published by Sindh Textbook Board for private and public higher secondary schools of Sindh, Pakistan. This study includes only books of English language that are being taught at the higher secondary levels. The narratives of those national heroes are discussed who either struggle for the partition from the India or who fought wars against the India after the establishment of Pakistan in 1947. The stories and events of such heroes are represented in small and isolated pictures, excluding events and the people belong to historical context in the most cases. This paper was aimed to investigate ideologies behind the representations through language, style, tone, content and images. The writings serve very important purpose. This is all about informing stories and narratives in a very convincing manner in order to enable the readers to see the story blindly and aggressively. The contents of texts intend to explore the heroism of national heroes. It can be explored by the styles and attitudes of portrayal of national heroes. It seemed that the texts and narratives are intended to propagate and promote heroism. The language and selections of words are focused to arise Islamic, national and anti-Indi feelings among young students. Each portrayal attempted to inculcate the patriotism in its youth or young readers. The curriculum designers implanted emotions and sentiments into the minds of youth through these textbooks. It is meant to emphasis the importance of Islam, nation and anti-national forces and also to leave long-lasting impressions on the minds of students. The narratives of national heroes narrate a big story that is told to students again and again about the struggles and troubles on which the state Pakistan is established and about the hardships and sacrifices that many people gave for the cause of freedom before and after its creation even during the partition. The text of Liaquat Ali khan is the best example of such narratives. The sole purpose of doing this is to create a strong bond between nation and its country. Nevertheless, they are creating such followers rather than blind patriots who do not raise questions regarding the validity and authenticity of information of past or future that continues to grow on the soil of misinformation from past history.

\section{Reference}

Ahmad, I. (2004). Islam, democracy, and citizenship education: An examination of the social studies curriculum in Pakistan. Current Issues in Comparative Education, 7(1). Retrieved from https://archive.org/stream/ERIC_EJ853848\#page/n3/mode/2up

Ahmed, I. (1998). State, nation and ethnicity in contemporary South Asia. London: Continuum International Publication. https://doi.org/10.1080/09584939808719835 


\section{Macrothink}

Ahmed, A. (2012). Jinnah, Pakistan and Islamic entity. London: Routledge.

Aliakbari, M., \& Jamalvandi, B. (2012). Realization of culture in English textbooks in Chinese high school level. Pan-Pacific Association of Applied Linguistics, 16(2), 89-100.

Bahman, M., \& Rahimi, A. (2010). Gender representation in EFL materials : an analysis of English textbooks of Iranian high schools, 9, 273-277. https://doi.org/10.1016/j.sbspro. 2010.12.149

Khan, Q., Sultana, N., Bughio, Q., \& Naz, A. (2014). Role of Language in Gender Identity Formation in Pakistani School Textbooks, 21(1), 55-84. https://doi.org/10.1177/097152 1513511200

Lall, M. (n.d.). Educate to hate - the use of education in the creation of antagonistic national identities in India and Pakistan .

Muhammad, Y. (n.d.). IARTEM e-Journal Volume 7 No 3 Volume 7 Number 3 Beyond binary discourses? Pakistan studies textbooks and representations of cultural, national, and global identity, 7(3), 74-101.

Presented, P., \& Conference, A. A. (2010). The Many Uses of Charisma: A Comparative Study of the Portrayal of National Heroes in Canadian and Egyptian School Texts Paper Presented to the ASEN Annual Conference.

Pathan, H., Shah, S. W. A., Lohar, S. A., Khoso, A. R., \& Memon, S. (2018). Language Policy and Its Consequences on Sindhi Language Teaching in Sindh, Pakistan. International Journal of English Linguistics, 8(5), 135. https://doi.org/10.5539/ijel.v8n5p135

Rahman, T. (2002b). Language, ideology and power. Karachi: Oxford University Press.

Pathan, H., Memon, R. A., Memon, S., Shah, S. W. A., \& Magsi, A. (2018). Academic Vocabulary Use inDoctoral Theses: A Corpus-Based Lexical Analysis of Academic Word List (AWL) in Major Scientific Disciplinary Groups. International Journal of English Linguistics, 8(4), 282. https://doi.org/10.5539/ijel.v8n4p282

Pathan, H., Lohar, S., \& Shah, SWA. (2015). Indus Identity: A Study of Textbooks in Pakistan. Lambert Academic Publishing

Shah, S. W. A., \& Pathan, H. (2016). Representation of Western Culture in O'level English Language Textbooks. In English Language Forum (ELF) (Vol. 18).

Yazici, S. (2011). Using Heroes as Role Models in Values Education : A Comparison between Social Studies Textbooks and Prospective Teachers' Choice of Hero or Heroines *. Educational Sciences: Theory and Practice, 11(4), 2184-2189.

\section{Copyright Disclaimer}

Copyright reserved by the author(s).

This article is an open-access article distributed under the terms and conditions of the Creative Commons Attribution license (http://creativecommons.org/licenses/by/3.0/). 